УДК 378.134.016:78

DOI https://doi.org/10.26661/2522-4360-2021-2-37

\title{
ТЕОРЕТИЧНІ ЗАСАДИ ДОСЛІДЖЕННЯ ТЕМБРОДИНАМІЧНОГО СЛУХУ У МАЙБУТНІХ УЧИТЕЛІВ МУЗИЧНОГО МИСТЕЦТВА В СУЧАСНОМУ НАУКОВОМУ ДИСКУРСІ
}

\author{
Ма Цзе \\ аспірантка кафедри музично-інструментальної підготовки \\ факультету музичної та хореографічної освіти \\ Д3 «Південноукраӥнський національний педагогічний університет \\ імені К. Д. Уиинського» \\ вул. Старопортофранківська, 26, Одеса, Украӥна \\ orcid.org/0000-0002-8695-0036 \\ 1498511882@qq.com \\ Демидова М. Г. \\ кандидат педагогічних наук, \\ доцент кафедри музично-інструментальної підготовки \\ факультету музичної та хореографічної освіти \\ Д3 «Південноукраӥнський національний педагогічний університет \\ імені К. Д. Уиинського \\ вул. Старопортофранківська, 26, Одеса, Україна \\ orcid.org/0000-003-2731-41-41 \\ mgdemidova@ukr.net
}

\begin{abstract}
Ключові слова:
тембродинаміка,

звуковисотний і ладовий слух, музичний тембр, тембри оркестрових інструментів, прийом звуковидобування, темброутворюючі функиіі засобів музичної виразності.
\end{abstract}

У статті наведено теоретичний аналіз дослідження проблеми формування тембродинамічного слуху як у зарубіжній, так і у вітчизняній педагогічній, музикознавчій та психологічній науках. Розкрито зміст цього поняття 3 різних концептуальних підходів. Виявлено особливості прояву даного виду слуху в учнів початкових спеціалізованих мистецьких навчальних закладів та студентів-музикантів у процесі музично-інструментальної підготовки. Доведено, що тембродинамічний слух діалектично пов'язаний i3 загальною музичною обдарованістю суб'єкта, яка виражається у високому ступені його емоційної сприйнятливості до музичних образів, художніх вражень і смислових асоціацій. У статті обгрунтовується протиріччя між традиційним послідовним формуванням звуковисотного й інтонаційного слуху, що характерні епохам класицизму і романтизму, i необхідністю формування нового типу сонорного слухового сприйняття, спрямованого на споглядання слухом якісних змін і особливостей тембрового звучання сучасних напрямів музики. Розглянуто поняття тембру в контексті оркестрового i фортепіанного виконавства. Виявлено особливості тембрального сприйняття оркестрової музики на основі класифікації тембрів оркестрових інструментів, яке сприяє як розмежуванню всіх компонентів оркестрової тканини, так і об'єднанню їх у структурне ціле. Враховуючи положення про монотембровість фортепіано, доведено, що цей інструмент володіє великим потенціалом тембральної інтерпретації, якість відтворення якої залежить від певного виконавського алгоритму. Наведений алгоритм включає такі складові частини: музично-образне осмислення музичного тексту, створення тембрально-слухових уявлень, підготовленість виконавського руху руки і присутність у процесі виконання певної манери. Доведено, що гра на 
фортепіано створює особливо сприятливі умови для розвитку тембродинамічного слуху, що диктується: а) особливостями виконавської діяльності (барвистість і різноманітність звучання, які є невід’ємним компонентом піаністичної експресії, смислу i виразності); б) особливостями самого інструменту фортепіано, який не має свого яскраво вираженого, специфічного, спочатку властивого йому тембру, проте у процесі виконання здатний створювати найбарвистіші темброві поєднання. У статті зроблено висновок про те, що основу тембродинаміки становлять індивідуальні якості звучання різних музичних інструментів і темброутворюючі функції засобів музичної виразності (динаміка, артикуляція, регістр).

\title{
THEORETICAL FUNDAMENTALS OF THE STUDY OF TIMBRE-DYNAMIC HEARING OF FUTURE MUSIC TEACHERS IN MODERN SCIENTIFIC DISCOURSE
}

\author{
Ma Jie \\ Postgraduate Student at the Department of Music and Instrumental Training \\ of the Faculty of Music and Choreography \\ State Institution "South Ukrainian National Pedagogical University \\ named after K. D. Ushynsky" \\ Staroportofrankivska str., 26, Odesa, Ukraine \\ orcid.org/0000-0002-8695-0036 \\ 1498511882@qq.com \\ Demydova M. H. \\ Candidate of Pedagogical Sciences, \\ Associate Professor at the Department of Music and Instrumental Training \\ of the Faculty of Music and Choreography \\ State Institution "South Ukrainian National Pedagogical University \\ named after K. D. Ushynsky" \\ Staroportofrankivska str., 26, Odesa, Ukraine \\ orcid.org/0000-003-2731-41-41 \\ mgdemidova@ukr.net
}

Key words: timbre dynamics, pitch and scale hearing, musical timbre, timbres of orchestral instruments, sound production, timbre-forming functions of the means of musical expression.
The article presents a theoretical analysis of the problem of of timbre-dynamic hearing formation in both foreign and domestic pedagogical, musicological and psychological sciences. The meaning of this concept from different conceptual approaches is revealed. The peculiarities of the manifestation of this type of hearing in students of primary specialized art schools and music students in the process of musical and instrumental training are revealed. It is proved that timbre-dynamic hearing is dialectically connected with the general musical talent of the individual, which is expressed in a high degree of his emotional susceptibility to musical images, artistic impressions and semantic associations. The article substantiates the contradiction between the traditional consistent formation of pitch and intonation hearing, which are characteristic of the epochs of classicism and romanticism, and the need to form a new type of sonorous auditory perception aimed at contemplating qualitative changes and features of timbre sound of the modern music. The concept of timbre in the context of orchestral and piano performance is considered. The peculiarities of timbre perception of orchestral music on the basis of classification of timbres of orchestral instruments are revealed, which promotes both delimitation of all components of orchestral fabric and their unification into a structural whole. Given the provisions on the mono-timbre of the piano, it is proved that this instrument has a great potential for timbre interpretation, the quality of which 
depends on a certain performance algorithm. The presented algorithm includes the following components: musical and figurative comprehension of the musical text, creation of the timbre-auditory representations, readiness of performing movement of a hand and presence in the course of performance of a certain manner. It is proved that playing the piano creates especially favorable conditions for the development of timbre-dynamic hearing, which is dictated by: a) the peculiarities of performance (color and variety of sound, which are an integral component of pianistic expression, meaning and expressiveness); b) the peculiarities of the instrument itself - the piano, which does not have its own pronounced, specific, initially characteristic timbre, but in the process of performance is able to create the most colorful timbre combinations. The article concludes that the basis of timbre dynamics are individual sound qualities of different musical instruments and timbre-forming functions of the means of musical expression (dynamics, articulation, register).

Постановка проблеми. У XX - XXI століттях увагу вчених у сфері музичної педагогіки і психології, інструментознавства, музичної акустики, психоакустіки, психофізіології слуху, нейропсихології сприйняття стало привертати вивчення різних видів слуху та його впливу на сприйняття суб'єктом атрибутивних властивостей звуку. У цьому контексті вченими розглядаються питання тембральної семантики (Б. Асафьєв, С. Назайкинський, Е. Денисов, І. Шабунова, Л. Шаймухаметова, В. Березін); окремих функцій тембру звуку (Б. Асафьєв, Л. Мазель, А. Шнітке, Е. Денисов), властивостей музичного тембру як формоутворюючого (I. Фінкельштейн, В. Цитович, С. Пономарьов), стилевідповідного факторів (В. Цитович, М. Шавінер, Ю. Михайлова, Ю. Кудряшов, С. Яроциньский, I. Новічкова, В. Ульянов та ін.). У музичній педагогіці також досліджуються питання використання нових прийомів тембрального звуковидобування як у сучасній музиці (А. Бартолоцці, А. Соколов, Н. Бажанов, М. Бенюмов, Д. Дувірак, А. Радвілович, М. Манафова та ін.), так і етноінструментоведення (О. Нікітенко, Дж. Михайлов, А. Алпатова, Н. Гілярова). Ф. Караєв, А. Маклигін, І. Шабунова досліджують вплив тембрального слуху на розвиток композиційних умінь. Д. С. Надировою досить широко проаналізовано явище внутрішнього вокального співінтонування при сприйнятті і переживанні музики, а також його роль у формуванні емоційного відгуку на музику, що звучить. Однак, у цих дослідженнях враховувався тільки звуковисотний чинник, у той час як тембродинамічний бік співінтонування і відповідні відчуття залишаються поза увагою [ 15, с. 34].

Професійний інтерес до винаходу і вдосконалення музичного інструментарію, а також прагнення знайти нові фарби звучань, нові темброві поєднання музичних інструментів, прийоми виразної гри сприяв появі в XIX столітті «математичної науки - інструментоведення», як відзначає у своїй монографії І.Б. Горбунова [с. 135].

У музичній теорії довгий час увагу вчених було спрямовано на вивчення звуковисотного слуху, при цьому не порушувалися такі його про- яви, як тембровість. Такий стан, як справедливо зауважує Ю. Рагс, відображає послідовність освоєння в музичній практиці виразних властивостей окремих елементів музичного цілого: «спочатку була освоєна висота, потім ритм, потім голосні, далі - різні перехідні процеси у звуках або поміж звуками - вібрато, атака, затухання, глісандо та інше» [9].

Виходячи із розвідок учених (П.М. Бережанський, Т. Боровик, Т.С. Бирченко, В.А. Вахромєєв, А. Каузова, В.І. Петрушин, Ю.Н. Рагс), слід виділити декілька визначень музичного слуху: «сукупність здібностей людини, що дозволяють їй повноцінно сприймати музику й адекватно оцінювати ті чи інші іiі переваги і недоліки»; «найважливіша професійна якість, необхідна для успішної творчої діяльності у сфері музичного мистецтва»; «тонка психофізіологічна чутливість, виражена у психоемоційній чуйності як щодо різних характеристик і якостей музичних звуків (висоти, гучності, тембру, нюансуванню тощо), так і щодо різних функціональних зв'язків між окремими звуками у цілісному контексті того або іншого музичного твору» $[4 ; 5 ; 7 ; 8 ; 12 ; 18 ; 21]$. Б.М. Теплов у своєму дослідженні відзначав, що музичний слух діалектично пов'язаний із загальною музичною обдарованістю людини, що виражається у високому ступені іï емоційної сприйнятливості до музичних образів, у силі й яскравості викликаних цими образами художніх вражень, смислових асоціацій і психологічних переживань [22].

Цікаве спостереження пропонує Т.О. Литвинова у своєму дисертаційному дослідженні. Вчена вказує, що у викладанні музично-теоретичних дисциплін переважає ставлення до тембру як до чогось другорядного і необов' язкового. Вона також вказує на надмірне орієнтування в сучасних музичних школах курсу сольфеджіо на формування звуковисотного слуху: «Система сольфеджіо, як відомо, починає прямо з інтонації і закінчує однією нею, втім за участю ритму. Характерною рисою іiі тому є те, що фарба і нюансування залишаються осторонь» [14, с. 165]. У наш час вивчення курсу сольфеджіо у початкових спеціалізованих мистецьких навчальних закладах здійснюється по лінії 
ускладнення звуковисотних, ладових і гармонійних характеристик звуку. водночас інструментальний матеріал у тембровому відношенні майже не розглядається. Переважаючим у навчанні студентів педагогічних факультетів також є звуковисотне, ладо-функціональне слухання, що пояснюється орієнтацією дисципліни «Основний музичний інструмент» на твори класичного стилю. Разом із тим у сучасних умовах найбільш актуальним стає тембральне сприйняття [10].

Протиріччя між традиційним історичним типом сприйняття, яке полягає у послідовному простеженні звуковисотного i інтонаційного розвитку у класичному i романтичному музичних стилях і формуванні нового типу слухового сприйняття - «сонорного типу», пов'язаного із спогляданням слухом якісних змін і особливостей тембрового звучання в сучасних напрямах музики, визначає актуальність цієї статті [10].

Мета статті. Проаналізувати теоретичні засади дослідження тембродинамічного слуху в сучасному науковому дискурсі та виявити специфіку його прояву у процесі фортепіанної підготовки майбутніх учителів музики.

Виклад основного матеріалу дослідження. Відомо, що тембр є одним із важливих засобів прояву емоцій у музиці. Тембру як одному із засобів художньої виразності емоційного змісту в музиці відводиться надзвичайно важлива роль. Особливе значення тембр набуває в інструментальному виконавстві. Тембр як засіб оркестрової виразності сприяє розмежуванню всіх компонентів оркестрової тканини. 3 його допомогою досягається ясна розчленованість музичних побудов або об'єднання їх у структурне ціле. У контексті оркестрового виконання тембр означає забарвлення звуку, завдяки якому розрізняються особливості звучання інструментів та їх поєднань. Тембр характеризується кількістю та інтенсивністю обертонів (часткових тонів), формантами (областями посилених часткових тонів у спектрі звуку) та іншими факторами. Цей засіб музичної виразності є важливим фактором музичної драматургії.

Вихідною класифікацією тембрів оркестрових інструментів є поділ їх на тембри чисті (тембр солюючих інструментів, а також всі унісонні поєднання тотожних інструментів) і змішані (результат поєднань різних тотожних інструментів). Кожен вид оркестру відрізняється своєрідністю тембрового колориту, що включає такі складові: інструментальні соло; унісони тотожних інструментів; унісони споріднених інструментів; унісони різних інструментів; ансамблі тотожних інструментів; ансамблі різних інструментів (однієї, декількох груп).

Тембровий колорит в оркестрі виражається у різноманітних комбінаціях чистих і змішаних тембрів. У словнику «Терміни та визначення в музиці» поняття тембровий колорит трактується як «регістрова своєрідність інструментів (збільшення тембрової напруженості у верхньому регістрі, послідовна зміна тембрових якостей при зміні регістрів)».

У статті також вказується, що тембровий колорит визначають прийоми виконання, передбачені «спеціальними ремарками, штрихами, динамічними відтінками, і способи зміни звуку», а також ступінь їх неподільності і контрасту при одночасному звучанні [1].

Тембр у контексті звуковидобування сольного інструменту має більш складний механізм відтворення. Так, фортепіано - монотембровий інструмент, що має великий потенціал тембральної інтерпретації, якість відтворення якої залежить від виконавського алгоритму, що включає музично-образне осмислення музичного тексту, тембрально-слухові уявлення, готовність виконавського руху руки і манеру виконання. Музичний текст - це повідомлення складного утворення в єдності двох його сторін: знакової фіксації авторського задуму (нотний текст) і художнього повідомлення, наповненого образно-смисловою змістовністю (музичний текст). Особливу роль у створенні образу відіграє пошук інтонаційного смислу у процесі вивчення твору. Згідно $з$ концепцією Б.В. Асафєва, «інтонація є головним провідником музичної змістовності, музичної думки, а також носієм художньої інформації, емоційного заряду, душевного руху» [2].

Тембрально-слухове уявлення, як другий виділений нами механізм алгоритму тембральноінструментального відтворення, тісно пов'язане 3 психологічною установкою на художню інтерпретацію музичного твору. Н.Г. Морозова таку установку називає методом «начебто», пов'язаним 3 випереджаючими уявленнями, яким підсвідомо підкоряються механізми управління виконавським процесом.

Використання методу «начебто» тісно пов'язане $з$ порівняльною асоціацією, викликає відповідні уявлення звучання конкретного музичного фрагменту в оркестрі. Такий підхід є визначальним, особливо у виконанні сонат віденських класиків, творчість яких збігається 3 періодом становлення і розвитку симфонічного жанру.

Тембрально-слухове уявлення грунтується також на порівняльній образній асоціації, що викликає відповідні уявлення у виконавця. Створення асоціації на рівні передслихання звуку або музичного фрагмента може грунтуватися на порівнянні певного звуку з конкретним предметом або явищем, внаслідок чого звуковий тембр може бути теплим, м'яким, яскравим, насиченим, різким, металевим тощо. За твердженням 
учених, образно-асоціативне мислення - це найвищий ступінь пізнання людиною дійсності, чуттєвих відчуттів, сприйняття і уявлень в образах [2]. Складність реалізації образно-асоціативного мислення у процесі роботи над музичним твором полягає в його комплексності та непередбачуваності одержуваних з його допомогою результатів, але саме ці якості (комплексність, непередбачуваність, здатність до логічного аналізу) складають основу людської психіки [22].

Готовність виконавського руху руки, яке ми виділяємо як третю складову частину алгоритму тембрально-інструментального відтворення, базується на відомому в музичній педагогіці феномені «руки, що чує» піаніста як функціональної системи антиципуючих кореляційних зв'язків слуху i моторики. Цей термін введений до практики C.I. Савшинським і має низку близьких за змістом назв: «локальна пам'ять рук» (Ф. Куперен), «жива рука» (А. Хальм). Представляючи собою функціональну систему кореляційних зв'язків слуху і моторики, «рука, що чує» координує між собою слухові прообрази і рухи виконавця. У результаті цього внутрішні слухові уявлення миттєво озвучуються і перетворюються в конкретний акустичний «продукт». Таким чином, музично-слухові уявлення передують і формують певне тембральне звучання. Саме характер звукових образів у сфері внутрішньо-слухових уявлень, що протікають поза опорою на реальне звучання фортепіано, впливає на вибір тих чи інших навичок тембрової імітації. Необхідно відзначити, що принцип антиципуючих рухів грунтується на достатньому та високому рівнях сформованості у виконавця музично-слухових навичок, пов'язаних із формуванням образу-уявлення у процесі роботи над музичним твором.

Останній елемент серед складових частин жанрово-виконавського алгоритму передбачає наявність у інтерпретатора виконавської манери, що представляє собою систему засобів виразності і способу самовираження.

Таким чином, гра на фортепіано створює особливо сприятливі умови для розвитку тембродинамічного слуху, що диктується:

- особливостями виконавської діяльності: барвистість і різноманітність звучання, його темброва характеристичність $є$ невід'ємним компонентом піаністичної експресії, смислу і виразності;

- особливостями самого інструменту - фортепіано, який не має свого яскраво вираженого, специфічного, спочатку властивого тільки йому тембру, проте у процесі виконання представляє можливість створювати найрізноманітніші барвисті темброві співзвуччя.

На підставі аналізу літературних джерел можна стверджувати, що основу тембродинаміки становлять:

- індивідуальні якості звучання різних музичних інструментів;

- темброутворюючі функції засобів музичної виразності (динаміка, артикуляція, регістр).

Динаміка як темброутворююча функція засобів музичної виразності пов'язана з кількістю і силою обертонів; артикуляція - з атакою звуку - «ритмічним процесом у звуці» або «темброутворюючою дією ритму» [6]; відмінність регістрів визначається відносинами висот обертонів. Індивідуальні якості звучання різних музичних інструментів разом із темброутворюючими функціями засобів музичної виразності складають ілюзорний тембр, який разом із реальним тембром представляє цю категорію в широкому іiі розумінні [6, с. 207-237].

У контексті цього С.В. Пономарьов висловлює твердження про те, що не існує абсолютно однотембрової музики: звук може бути звуковисотно або ритмічно невизначеним, але «той чи інший тембр завжди є у звуку» [20, с. 15-23].

Висновки і перспективи подальших розробок у цьому напрямі.

Таким чином, у статті проаналізовано теоретичні засади дослідження тембродинамічного слуху в сучасному науковому дискурсі та виявлено специфіку його прояву у процесі фортепіанної підготовки майбутніх учителів музики.

Доведено, що тембральна інтерпретація музичного твору на фортепіано включає: музично-образне осмислення музичного тексту, тембрально-слухові уявлення, готовність виконавського руху руки і манеру виконання.

Формування тембральної техніки піаніста грунтується на: формуванні особливого піаністичного туше, присутності свободи виконавського апарату, наявності еталона звучання, слуховій увазі, володінні технікою педалізації, активності уяви, контролі якості звучання.

Перспективними напрямами подальших досліджень вважаємо наукове обгрунтування компонентної структури та критеріїв оцінювання рівня сформованості тембродинамічного слуху у майбутніх учителів музичного мистецтва у процесі опанування фортепіанними творами.

1. https://domifa.ru/

\section{ЛІТЕРАТУРА}

2. Асафьев Б.В. Музыкальная форма как процесс. Книги первая и вторая «Музыка», 1971. 376 с.

3. Бережанский П.Н. Абсолютный музыкальный слух [Электронный ресурс]. М., 2000. 101 с. http://www.absolute-pitch.ru 
4. Бондаренко А. До проблеми типології акустичних подій в сучасній електронній музиці (на прикладі твору О. Нестерова «Кольорова флюографія»). Музичне мистецтво і культура. Науковий вісник ОНМА імені А. В. Нежданової. 2020. Т. 2, Вип. 30. С. 18-29.

5. Боровик Т. Ансамблевое музицирование в классе сольфеджио [Электронный ресурс]: http://borovik.ucoz.ru/ 1

6. Будников В. В. Тембральность фортепианной фактуры в исполнительском тексте: на примере произведений Н. К. Метнера: диссертация ... кандидата: 17.00.02. ФГБОУ ВО «Новосибирская государственная консерватория имени М.И. Глинки», 2020.

7. Бырченко Т. С песенкой по лесенке. Методическое пособие для подготовительных классов. М.: Сов. композитор, 1983. $112 \mathrm{c.}$

8. Вахромеев В. А. Вопросы методики преподавания сольфеджио в ДМШ. М.: Музыка, 1978. 88 с.

9. Горбунова И. Б. Архитектоника звука: монография. Санкт-Петербург: Издательство РГПУ им. А.И. Герцена, 2014.

10. Денисов А. Метаморфозы музыкального текста 2-е изд., М.: Юрайт, 2018. 189 с.

11. Єременко О. В. Теорія і методика розвитку музичного сприймання в учнів основної школи. Суми, 2003.

12. Каузова А. Музыкальный слух. Теория и методика обучения игре на фортепиано (под общ. ред. А. Каузовой, А. Николаевой). М.: ВЛАДОС, 2001. С. 65-90.

13. Кущ Є.В. Електромузичний інструментарій як еволюційний фактор музичної культури: монографія. К.: НАКККіМ, 2015. 160 с.

14. Литвинова Т. . Тембровый слух: онтологический и гносеологический аспекты. Санкт-Петербург, $2011.340 \mathrm{c}$.

15. Надырова Д.С. Музыкальное развитие в процессе фортепианного обучения: Учебное пособие. Казань: Изд-во ТГГПУ, 2008. 95 с.

16. Педагогіка і психологія професійної освіти: результати досліджень і перспективи. К.: КПЕК.

17. Пен Сіює. Основні аспекти підготовки майбутніх учителів музичного мистецтва до розвитку тембрального слуху учнів // Педагогічні науки: теорія, історія, інноваційні технології, 2020. № 8 (102). C. 468-476. DOI: 10.24139/2312-5993/2020.08/468-476.

18. Петрушин В.И. Музыкальная психология: Учеб. пособие для вузов. 2-е изд. М.: Академический Проект; Трикста, 2008. 400 с.

19. Позднякова Т.И., Лосева С.Н. Музыкальный слух как компонент музыкальной одаренности в вокально-хоровой деятельности // Вестник КГПУ им. В.П. Астафьева. 2017. № 2 (40).

20. Пономарев С.В. К проблеме формообразующего действия инструментовки. Тембротектонические принципы музыкальной формы // Музыковедение (рекомендовано ВАК). 2010. № 5. С. 15-23.

21. Рагс Ю.Н. Слух музыкальный [Электронный ресурс]: http://www.belcanto.ru

22. Теплов Б.М. Психология музыкальных способностей. М.: Наука, 2003. 384 с.

23. Цытович В. Некоторые аспекты тембровой драматургии // Современные вопросы музыкознания. М.: Музыка, 1976. С. 207-237.

1. https://domifa.ru/

\section{REFERENCES}

2. Asafev, B.V. (1971). Muzyikalnaya forma kak protsess [Musical form as a process]. Knigi pervaya i vtoraya "Muzyika".

3. Berejanskiy, P.N. (2000). Absolyutnyiy muzyikalnyiy sluh [Absolute ear for music]. M. URL: http://www.absolute-pitch.ru.

4. Bondarenko, A. (2020). Do problemy typolohii akustychnykh podii v suchasnii elektronnii muzytsi (na prykladi tvoru O. Nesterova «Kolorova fliuohrafiia») [On the issue of typology of acoustic podias in contemporary electronic music (on the example of O. Nesterov's "Coloured fluography")]. Muzychne mystetstvo i kultura. Naukovyi visnyk ONMA imeni A. V. Nezhdanovoi, Vol. 2, Vyp. 30, P. 18-29.

5. Borovik, T. Ansamblevoe muzitsirovanie v klasse solfedjio [Ensemble music-making in solfeggio class]. http://borovik.ucoz.ru/.

6. Budnikov, V.V. (2020). Tembralnost fortepiannoy fakturyi v ispolnitelskom tekste: na primere proizvedeniy N. K. Metnera [The timbre of the piano texture in the performing text: on the example of the works of N. K. Medtner] ( $\mathrm{PhD}$ thesis). FGBOU VO «Novosibirskaya gosudarstvennaya konservatoriya imeni M.I. Glinki».

7. Byirchenko. T. (1983). S pesenkoy po lesenke [With a song on the ladder]. Metodicheskoe posobie dlya podgotovitelnyih klassov. M.: Sov. kompozitor. 
8. Vahromeev, V.A. (1978). Voprosyi metodiki prepodavaniya solfedjio v DMSH [Questions of the methods of teaching solfeggio in children's music schools]. M.: Muzyika.

9. Gorbunova, I.B. (2014). Arhitektonika zvuka [The architectonics of sound]. Cankt-Peterburg: Izdatelstvo RGPU im. A.I. Gertsena.

10. Denisov, A. (2018). Metamorfozyi muzyikalnogo teksta [Metamorphoses of musical text]. M.: Yurayt.

11. Yeremenko, O.V. (2003) Teoriia i metodyka rozvytku muzychnoho spryimannia v uchniv osnovnoi shkoly [Theory and methods of musical perception development in primary school students]. Sumy.

12. Kauzova, A. (2001). Muzyikalnyiy sluh [Musical hearing]. Teoriya i metodika obucheniya igre na fortepiano (pod obsch. red. A. Kauzovoy, A. Nikolaevoy). M.: VLADOS. P. 65-90.

13. Kushch, Ye.V. (2015). Elektromuzychnyi instrumentarii yak evoliutsiinyi faktor muzychnoi kultury [Electromusical instruments as an evolutionary factor of musical culture]. K.: NAKKKiM.

14. Litvinova, T.A. (2011). Tembrovyiy sluh: ontologicheskiy i gnoseologicheskiy aspektyi [Timbre hearing: ontological and epistemological aspects]. Sankt-Peterburg.

15. Nadyirova, D.S. (2008). Muzyikalnoe razvitie v protsesse fortepiannogo obucheniya [Musical development in the process of piano learning]. Kazan: Izd-vo TGGPU.

16. Pedahohika i psykholohiia profesiinoi osvity: rezultaty doslidzhen i perspektyvy [Pedagogy and psychology of professional education: results and advances and perspectives]. K.: KPEK.

17. Pen Siiuie (2020). Osnovni aspekty pidhotovky maibutnikh uchyteliv muzychnoho mystetstva do rozvytku tembralnoho slukhu uchniv [The main aspects of the preparation of maybutny teachers of musical art to the development of the timbre hearing of scientists]. Pedahohichni nauky: teoriia, istoriia, innovatsiini tekhnolohii, 8 (102). P. 468-476. DOI: 10.24139/2312-5993/2020.08/468-476.

18. Petrushin, V.I. (2008). Muzyikalnaya psihologiya [Musical psychology]. M.: Akademicheskiy Proekt; Triksta.

19. Pozdnyakova, T.I., Loseva, S.N. (2017). Muzyikalnyiy sluh kak komponent muzyikalnoy odarennosti $\mathrm{v}$ vokalno-horovoy deyatelnosti [Musical ear as a component of musical giftedness in vocal and choral activity]. Vestnik KGPU im. V.P. Astafeva. № 2 (40).

20. Ponomarev,S.V.(2010).Kproblemeformoobrazuyuschegodeystviyainstrumentovki. Tembrotektonicheskie printsipyi muzyikalnoy formyi [On the problem of the formative action of instrumentation]. Muzyikovedenie (rekomendovano VAK). № 5. P. 15-23.

21. Ragc, Yu. H. Sluh muzyikalnyiy [Musical hearing]. URL: http://www.belcanto.ru.

22. Teplov, B.M. (2003). Psihologiya muzyikalnyih sposobnostey [Psychology of musical abilities]. M.: Nauka.

23. Tsyitovich, V. (1976). Nekotoryie aspektyi tembrovoy dramaturgii [Some aspects of timbre drama // Modern issues of musicology] // Sovremennyie voprosyi muzyikoznaniya. M.: Muzyika. P. 207-237. 